\title{
AN INTEGRATED APPROACH TO RISK ASSESSMENTS AND CONDITION SURVEYS
}

\author{
JOEL TAYLOR
}

Understanding something in just one way is a rather fragile kind of understanding.... you need to understand something in at least two different ways to really understand it. Each way of thinking about something strengthens and deepens each of the other ways of thinking about it. Understanding something in several different ways produces an overall understanding that is richer and of a different nature than any one way of understanding.

—Resnick 1994, 103

ABSTRACT - This article discusses the integration of risk assessment and collection condition surveys, with reference to the uncertainties inherent in each of these two procedures. While condition surveys provide information on a collection's immediate condition, risk assessments add predictive aspects on the collection's potential for deterioration. Looking at probable causes of damage in a condition assessment can provide a link to the agents of deterioration examined in a risk assessment. Combining these two complementary assessments can provide useful insights and clarify priorities for the collection's management goals. Comparison of the advantages and disadvantages of two types of evaluation processes in visual perception, top-down and bottom-up, are discussed as they apply to the integration of the two assessments. Additionally, the article describes the use of an integrated assessment approach for a survey of the English Heritage collections. In conclusion, it was found that integrating condition surveys with risk assessments could increase the knowledge and understanding of current and future expectations of a collection.

TITRE-Une approche intégrée pour l'évaluation des risques et de l'état des collections. RÉSUMÉCet article traite de l'intégration de l'évaluation des risques et de l'état des collections en faisant référence aux incertitudes inhérentes à chacun de ces processus. Alors que l'évaluation de l'état des collections fournit de l'information sur la situation actuelle d'une collection, l'évaluation des risques prédit les possibilités de détérioration d'une collection. Examiner les causes probables de dommage lors d'une évaluation de l'état des collections peut permettre de faire des liens entre ces causes et les agents de détérioration considérés au cours d'une évaluation des risques. Joindre ces deux évaluations complémentaires peut donner un aperçu utile et aider à identifier des priorités afin d'atteindre les objectifs de gestion de collection. Une comparaison est faite des avantages et désavantages des deux types de processus d'évaluation reliées à la perception visuelle, soit directe ou indirecte, tel qu'ils sont appliqués à l'intégration des ces deux types d'évaluation. L'article décrit aussi l'usage d'une approche d'évaluation intégrée pour les collection de English Heritage (Patrimoine d'Angleterre). En conclusion, on démontre qu'en intégrant une évaluation de l'état des collections avec une évaluation des risques, on peut accroître la connaissance et la compréhension des attentes courantes et futures d'une collection.

TITULO_Enfoque integrado de las evaluaciones de riesgo y encuestas de condición. RESUMEN-Este artículo discute la integración de las evaluaciones de riesgo y las encuestas de condición de colecciones, con referencia a las incertidumbres propias de cada uno de estos dos procedimientos. Mientras que las encuestas de condición proveen información sobre las condiciones inmediatas de las colecciones, las evaluaciones de riesgo le suman aspectos predictivos al potencial de deterioro de las colecciones. Mirar hacia las causas probables de daño en una encuesta de condición puede proveer un enlace con los agentes de deterioro que se examinan en la evaluación de riesgo. La combinación de estas evaluaciones complementarias puede proveer una comprensión útil y clarificar prioridades para los objetivos de gestión de las colecciones. La comparación de las ventajas y desventajas de los dos tipos de procedimientos de evaluación en cuanto a percepción visual, de arriba a abajo y de abajo hacia arriba, son discutidas en lo referente a su aplicación para la integración de las dos evaluaciones. Adicionalmente, el artículo describe el uso de un enfoque integrado de evaluación para el inventario de las colecciones de English Heritage (Patrimonio Inglés). En conclusión, se encontró que integrando las encuestas de condición con las evaluaciones de riesgo, se puede aumentar el conocimiento y el entendimiento de las expectativas actuales y futuras de una colección.

TÍTULO-Uma Visão Integrada Sobre aValia Ções de Riscos e Levantamentos do Estado de Coleções. RESUMO-Este artigo discute a integração da avalição de risco e do levantamento do estado de coleções, com referência ‘as incertezas inerentes a cada um destes 


\section{JOEL TAYLOR}

procedimentos. Enquando levantamentos do estado de coleções proporcionam informações sobre a condição imediata de uma coleção, avaliações de risco adicionam aspectos previsíveis sobre o potencial de deterioração da coleção. Observando-se as causas prováveis de danos no levantamento do estado da coleção, é possível vinculálas aos agentes de deterioração examinados na avaliação de risco. Combinando-se estas duas avaliações complementares é possível obter critérios úteis e aclarar prioridades no gerenciamento das coleções. São discutidas comparações das vantagens e desvantagens destes dois tipos de processos de avalia,cão na percepção visual, de cima para baixo e debaixo para cima, no que se aplica ’a integração das duas avialiações. Além disto, este artigo descreve a utilização de uma avaliação integrada para o levantamento da condição das coleções do English Heritage (Patrimônio Inglês). Finalmente, achou-se que a integração do levantamento do estado das coleções com a avaliação de risco poderia aumentar o conhecimento e o entendimento de atuais e futuras expectativas de uma coleção.

\section{INTRODUCTION}

The growth of risk assessment and risk-based models in preventive conservation has been considerable over the last 10 years (Waller 2002), making conservation planning a more rational process (Waller 2003). Risk assessment - the evaluation of potential damage from identified hazards to collections-is an extremely useful concept for preventive conservation and planning because it does not rely on the existence of damage to establish priorities for its prevention. Risk management - the generation, selection, and implementation of options to accept, reduce, or change risks - requires information that has a rational framework, such as risk assessment, to evaluate and select appropriate options for the preservation of cultural heritage. Waller states that "forecast risk, rather than measured damage to cultural property, is the appropriate measure to manage the preservation function of a museum. Measurement of collection condition over time will provide verification (or not) of the efficacy of the preservation function but not by itself provide sufficient information to monitor or plan the preservation function" (Waller 2002, 102).

Collection condition cannot be used to predict the future, but using more than one perspective, such as including empirical information about condition, can give perception of risk greater depth and clarity. For example, when exposure to a risk is identified but the collection is stable, or objects are deteriorating within accepted levels, resources could be spent on resolving issues that are not affecting the collection as much as other risks. Although intersurveyor differences may be the root of some of this discrepancy, the forecasting of damage and the behavior of objects can highlight where that discrepancy is (regardless of the reason) and illustrate areas that may need further analysis. In some cases, empirical information, such as collection condition, can refine this assessment. Introducing concepts of perception to risk assessment can help integrate such information. This article looks at visual perception as an analog to inferring from risk and condition assessments, since it provides more information than any of the other senses (Eysenck and Keane 2000). Cognitive psychologists and philosophers of science investigating decision making have drawn analogies with the key principles of visual perception (e.g., Tversky and Kahneman 1974; Oaksford and Chater 1998; Chalmers 1999). However, this article is not intended to be a review of the visual perception field.

\section{RISK ASSESSMENTS AND COLLECTION CONDITION SURVEYS}

Condition surveys collect preselected kinds of information about an object's deterioration regardless of its past. Past events cannot always help to predict future ones, however (Waller 2002, 2003). Risk assessments may give an indication of the environment to which a collection is exposed. Without knowing the collection's condition, collections management decisions created by assessing risk are not necessarily based on what is affecting the collection but on what might affect the collection or what control is not in place.

Waller (2002) maintains that risk management or assessment should not be interpreted on the basis of collection condition, arguing through the case of a stray bomb damaging a collection in a highly unpredictable way as evidence (after Crumly 1984). Waller (1994) has divided risks into three separate types, based on their severity and frequency (fig. 1). These risk types fall into one of two categories when assessing probability of damage to collections (Waller 1994, 2003), referred to as "catastrophic" and "deterministic" risks by Ashley-Smith (1999). Collection information may not inform assessments of catastrophic risks, but evidence of deterministic risks is often created during a collection's exposure to environmental hazards, if 


\section{AN INTEGRATED APPROACH TO RISK ASSESSMENTS AND CONDITION SURVEYS}

they are damaging the collection.

Waller's hypothetical example of a risk assessment (1999) using pollutants did not involve assessment of condition or stability, although the probability of damage was considered to be certain (probability of 1) for all the pollutants assessed (Waller 1999). This certainty of damage is the case for all type 2 and type 3 risks (Waller 2003).

Inferring risk of deterioration from data at any level is based on a theoretical framework of environmental conditions that are suitable or unsuitable for the preservation of objects. It is this theoretical framework within which risk assessments and condition surveys often operate (e.g., Thomson 1986; Michalski 1990, 1994; Erhardt and Mecklenburg 1994; Marcon 1997). The information recorded is conceptual, based on an understanding of how objects deteriorate, using indicators recognized within the framework to help make inferences for collection or risk management. However, Ashley-Smith (2000) points out that there is not a direct relationship between the potential for deterioration and actual deterioration. Not using evidence that a collection might provide means that the theoretical framework of deterioration is preferred over the actual interactions between a collection and its environment.

Risk assessment requires effect to be inferred from cause in a similar way that condition surveys require cause to be inferred from effect. Condition surveys can be used to determine past causes from existing effects (Keene 1991, 2002) and risk assessments forecast possible effects from potential causes (Waller 1994, 2002). "Conservators are repeatedly confronted by damaged objects and are in a position to build a formal or anecdotal database relating condition to probable cause of deterioration" (Ashley-Smith 1997, 123).

As Ashley-Smith (1999) and Waller (2002) state,

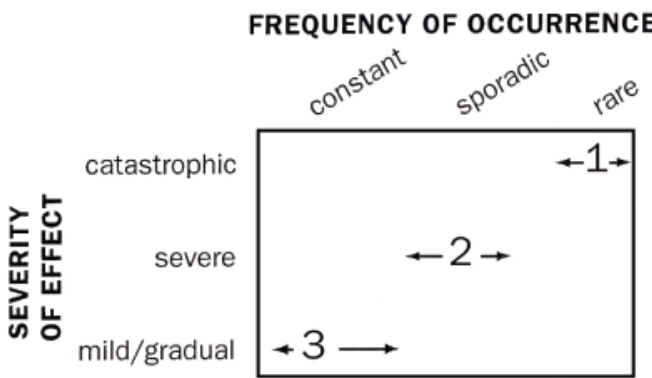

Fig. 1. Waller's $(1994,12)$ diagram categorizing risks in terms of their frequency and severity condition surveys often record effects rather than probable causes, so using condition surveys for preventive purposes can be difficult, because damage may have already occurred and not be related to current risks. Taylor and Watkinson (2003) point out that damage categories do not always reflect a particular hazard or set of hazards. And when the damage relates to more than one category, the interpretive possibilities increase and can lead to uncertainty in interpretation.

However, both kinds of inference are based on the theoretical framework that has been created for conservation, particularly interactions based on the agents of deterioration set out by Michalski (1990). Condition surveys are "backward-looking" (Waller 2002, 104), yet provide information about actual rather than predicted damage. Risk assessments are speculative but do not require damage for interpretation. Both are assessments of a situation at a particular point in time.

Looking at the whole history of a collection's condition does mean that fortune, and objects' existences before their museum accession, will be assessed as part of the museum's preservation function. However, Keene (2002) states that various "elements" contribute to a condition score (fig. 2), including "stability," which is related to the visible interaction of the object with various hazards. Condition surveys can reveal evidence of ongoing deterioration from deterministic hazards (Johnsen 1999), such as RH, visible and UV radiation, and pollutants, as well as objects' inherent instability.

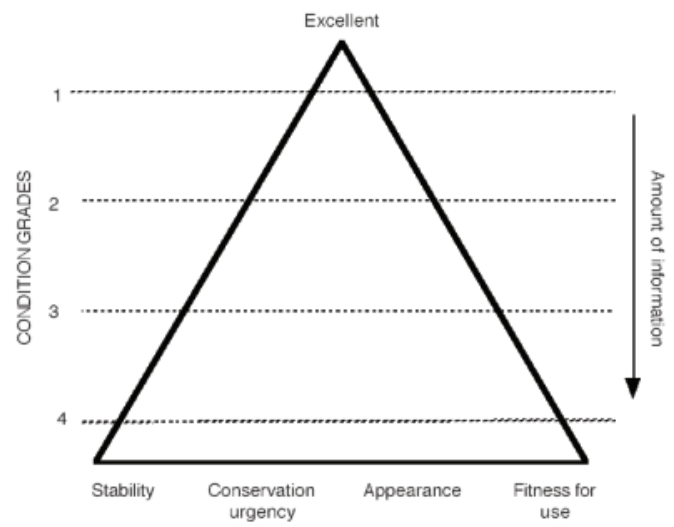

Fig. 2. Keene's (Keene 2002, 147) diagram of the elements involved in condition scoring illustrates the different kinds of condition that can be assessed. 


\section{JOEL TAYLOR}

Condition surveys can even be used to show that no deterioration has occurred, and have been used to justify existing preventive conservation procedures (Johnsen 1999).

This is not to say that risk assessments do not involve looking at the collection, or that condition surveys do not involve prediction, but the methods are not often connected. It is important to know whether exposure to a hazard and object condition are related. Van der Reyden et al. (1996) have used both in assessments of drawings in an Angel project that created a system of matrices, including use, exposure, condition, and risk, to prioritize preservation needs. This system was developed to give priorities to the needs of different collections, so no diagnostic link between the kind of risk and kind of damage was intended.

Johnsen and Bonde-Johansen (2002) used condition surveys and time-weighted preservation indices (TWPI) to determine the most suitable storage locations for objects based on life expectancy for planning, but the survey was not intended to assess risk.

Other condition assessments involving risk have looked at risk to single objects rather than to collections (Eden et al. 1998). Risks are often external, especially type 1 risks, such as floods, or very hard-tomake predictions from single objects, such as environmental risks. Assessing risk to objects at an item-by-item level may be possible for some kinds of chemical stability, but it is limiting for many risks and objects and cannot detect future changes or reveal a complete picture (Waller 2003).

In brief, it could be argued that risk assessments are more suitable for catastrophic, type 1 risks, and condition surveys for deterministic, type 3 risks.

\section{THE CAUSE-EFFECT RELATIONSHIP}

Cause-effect relationships in complex museum environments are by no means direct (Koestler et al. 1994; Ashley-Smith 1999, 2000). There are object-environment interactions that may not be immediately visible but are nevertheless destructive, such as lowering of $\mathrm{pH}$ and different reaction rates between objects. Assessing effects does not necessarily indicate the risks a collection faces. Equally, assessing exposure does not necessarily indicate consequence. Condition is difficult to diagnose, and risks may be benign, so interaction between risks and condition is difficult to establish.

The presence, or absence, of causes and effects does not tell the whole story. Using one perspective will produce different kinds of problems when assessing risk or consequence. Kinds of inference that can be used to characterize a cause-effect relationship for risk assessments and condition surveys, and their potential difficulties, are presented in table 1.

The behavior of objects within given environments does not always conform to the theoretical framework (Padfield 1994; Ashley-Smith 2000). There are various examples of objects and collections that have deteriorated in an unpredictable way

Table 1. Kinds of Inference and Their Potential Problems in Preventive Conservation Assessment

\begin{tabular}{lll}
\hline Relationship & $\begin{array}{l}\text { Type of } \\
\text { Inference }\end{array}$ & Problems Associated with Inference \\
\hline Cause-Effect & Inductive & $\begin{array}{l}\text { The "cause" of deterioration to which objects are exposed may not } \\
\text { have an effect on the objects (Ashley-Smith 2000). All causes would } \\
\text { be treated the same regardless of their impact on the collection. }\end{array}$
\end{tabular}

No cause-No effect Deductive Unusual phenomena would not be found, such as mold at moderate RH. Inherently unstable objects may not need an unsuitable environment to deteriorate.

Effect-Cause Inductive There is often more than one cause of deterioration (Koestler et al. 1994). Condition data recording effects may not differentiate between causes. Past deterioration may also be a problem, since the cause may no longer be present but the effects are visible.

No effect-No cause Deductive The effects may be present but not easily detected, such as an increase in $\mathrm{pH}$. Because an object or collection has not responded to a risk, it does not mean that relatively new problems or rare, catastrophic risks do not exist. 


\section{AN INTEGRATED APPROACH TO RISK ASSESSMENTS AND CONDITION SURVEYS}

(Grzywacz and Tennent 1994; Purewal 1997; AshleySmith 2000) and deteriorated within conditions that had been considered to be acceptable (Johnsen 1994; Keene 1994; Julien 2001) or remained stable in conditions outside "acceptable" levels (Padfield 1994; Bradley and Thickett 1999; Van Oosten 2002). There are also problems such as deterioration not being evident (Fenn 1995) and observations being subjective for both risk assessment (Waller 1994; AshleySmith 1997) and condition surveys (Newey et al. 1993; Taylor and Stevenson 1999).

Risk and condition can be related to these concepts in terms of expectation and observation. Risk assessment is forecasting the probability of events through the use of an existing theoretical framework of damage to objects-the expectation of damage. Condition surveys collect visible data to determine problems relating to collections-the observation of damage. Perceptions in these assessments are based on our knowledge of deterioration. The experience built up over time sharpens our perception, but it can also mean that the information perceived is based on rules created from past experiences.

\section{TOP-DOWN (INDIRECT) AND BOTTOM-UP (DIRECT) PROCESSING}

Waller $(1994,2003)$ comments on the uncertainty that is inherent within risk assessment, noting that "we do not currently have the knowledge required to do this precisely" (Waller 1994, 12). It is this ambiguity in expectation and the ambiguity of observation within collection condition surveys (Taylor and Stevenson 1999; Taylor and Watkinson 2003) that are important to recognize. Using these two techniques together to temper each other may reduce the uncertainty.

Visual perception has traditionally been divided into two contrasting theories: top-down processing, by which the mind guides representation of objects before the stimulus is processed, and bottom-up processing, by which an array of stimuli determine our perception. Since their conception, these conflicting theories have been integrated by various workers (Neisser 1976; Marr 1982) to accommodate their advantages and shortcomings. When integrated, the relative contributions of these processes will vary from situation to situation (Eysenck and Keane 2000). They are affected by the amount of information that can be retrieved from a situation, and by existing knowledge about the object or space. Top-down processing creates expectations of the world around us based on our experience. Bottom-up processing involves the more information-rich data that the world contains. By recording this information into a new framework, an added layer of perception through which the world is represented, and therefore viewed, lies between the conservator and an understanding of the risks to their collections. This integration of seemingly opposing approaches has led to a clearer understanding of visual perception. In terms of condition surveys, it is a way of creating a framework for interpreting the data. In terms of risk assessments, it is a way of incorporating information-rich aspects of the environment.

\subsection{TOP-DOWN PROCESSING}

Top-down processing is based on knowledge and bringing knowledge to the perceptual event. What we have perceived in the past affects what we perceive in our present environment. This representation is supplemented by sensory information. Everyday perception is frequently supplemented by what we know; for example, the shape of an object seen from only one angle is afforded a three-dimensional representation. Perception, as a result, is guided by what information the perceiver selects (fig. 3). What is important for accurate perception, in top-down terms, is context.

Top-down processing has clear parallels with data used in preventive conservation, since the information is recorded in predetermined categories based on a theoretical construct - the deterioration of materials under certain conditions. Condition survey forms provide a basic conceptual context for the information to be processed-an expectation to a certain extent-but risk assessment creates an actual frame-

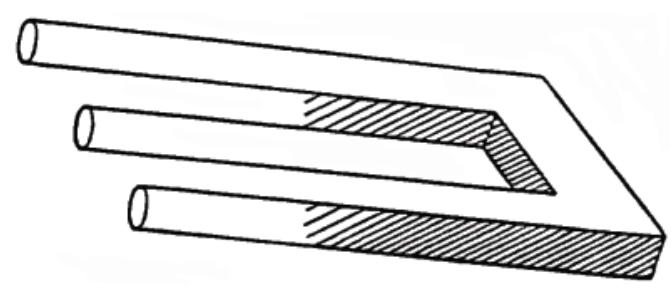

Fig. 3. The devil's fork. The image illustrates the tension between the image presented and the interpretation of it based on the perceptual rules we use. The illusion is known at a conceptual level, yet it still deceives. 


\section{JOEL TAYLOR}

work based on this conceptual understanding. This point is pertinent, since the environment to which a collection is exposed at a particular point in time is much like an individual percept from which one must interpret.

Top-down processing describes a process that can be subjective, in that the information is led by past experiences to create explanations, even hypotheses (Gregory 1972, 1974, 1998), of stimuli around them. However, the top-down theory does not provide a complete picture. For example, top-down processing does not account for the similarities between different perceptions.

\subsection{BOTTOM-UP PROCESSING}

Bottom-up processing is related to the role of the data. Here the information being viewed, rather than the perceiver, is the starting point of perception. The process is similar to the way condition surveys are purported to collect data, in which information is collected and then interpreted. Individual interpretation is not heavily involved in bottom-up processing. Information is not perceived as an abstract image but in its context, so it is very information-rich. However, background knowledge is not considered a significant factor in bottom-up processing, so the framework for interpreting data is not well developed.

As condition surveys collect data from an information-rich environment to be recorded and interpreted, the snapshot results have much in common with bottom-up perception that involves a single percept. Since bottom-up theory offers little in terms of how information is interpreted, it has more in common with empirical approaches to collection assessment. The two theories directly conflict on several points, which are mentioned in table 2 .

\section{THEORETICAL INTEGRATION}

It is clear that every perceptual situation requires an element of both types of processing, the proportion differing in each situation. Everyday navigation requires more bottom-up processing, whereas representing concepts requires more top-down processing. Risk assessments and condition surveys involve both, although risk assessment focuses on top-down expectation, and condition surveys on bottom-up observation. Each has advantages and drawbacks.

Neisser (1976) offered an example of how the two theories can be satisfied in his analysis-bysynthesis model (fig. 4). He claims that people do not see their retinal images but see with the aid of them (Neisser 1968). For each perceptual task, perceivers choose relevant information from all the information available. The constantly changing environment around us is an example of the need to select appropriate information rather than to perceive all elements of an extremely complex environment with equal importance.

Hypotheses about the perceived objects are continually updated with new information, which is stored to increase accuracy of future perceptions. This process is much like risk assessment being refined by perceptual exploration based on theoretical understanding. What is brought to the perceptual act is a "schema," internal to the perceiver (Neisser 1976),

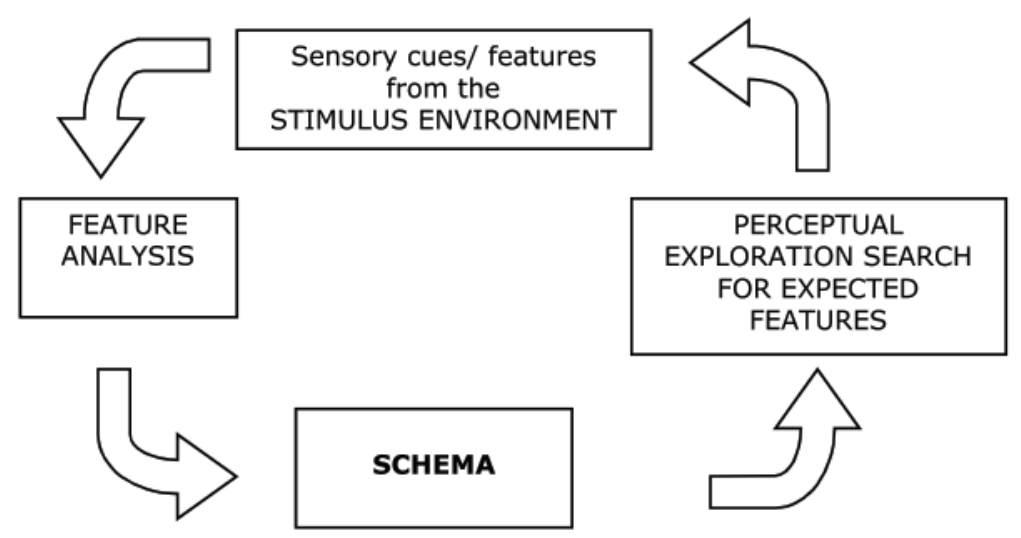

Fig. 4. Neisser's (1976) analysis-by-synthesis, as represented by Gross (2001, 224) 


\section{AN INTEGRATED APPROACH TO RISK ASSESSMENTS AND CONDITION SURVEYS}

Table 2. Some Respective Elements of Top-Down and Bottom-Up Processing

Top-down (Indirect) Processing
Perception is an active, constructive process.
Perception is inferred rather than innate, and
therefore prone to error.
Perception is individual and stems from assumptions
used to explain ambiguous information.

We do not always see objects, but we decide what they are by synthesizing a model based on previous experiences.

The perceiver infers beyond the information given.

Memory and interpretation play a vital role in perception, possibly creating a hypothesis of the image.

The theory is derived from experimental information and is thought to place too much emphasis on differences in perception (Gibson 1974, 1979).

If hypotheses are used, top-down theory does not explain how they are modified (Gordon 1989).
Bottom-up (Direct) Processing

Objects themselves determine perception. No

internal representation is involved.

Perception is innate rather than inferred, and therefore consistent.

Different observations are too alike to be indirect and come from picking up information rather than looking for it.

Perception comes from perceivers' picking up information from an "array of light" that is unambiguous and detailed.

Information is received, and only then does the interpretation take place.

Objects are seen in relation to their environment, not abstractly, so perception is "ecological," not contrived.

The direct manner of perception is considered too simple by some (Gregory 1998) and cannot explain differences in perception (Gordon 1989).

Bottom-up processing fails to do justice to the wealth of perception (Marr 1982).

Note: Some of these qualities oppose each other.

which is used to receive or organize expected information (Best 1995), although not necessarily at a conscious level. The "schema" is conceptual knowledge, such as object deterioration, that is built up from the empirical information in an environment, such as collection condition. According to Neisser, "neither perception nor memory is a copying process" (italics in original) (Neisser 1968, 252). The difference between human perception and conservation assessments is that perception, according to Neisser (1976), is a dynamic process that is constantly updated, whereas conservation assessments are sequential, linear processes often used as "snapshots."

Such a model is not appropriate for assessments carried out infrequently, but the advantages of a cyclical process, in which visible consequences can refine perceptions through organizing relevant information, is a useful analog for preventive conservation. The creation of a system in which expectations and observations can be assessed in light of each other pinpoints discrepancies, which creates a sharper assessment.

Marr (1982) has offered an influential theory by which perception is constructed through three autonomous stages that build up and increase in detail (fig. 5). Marr provides an explanation of perception at a local level that accounts for the richness of our perceptual worlds, and also for the differences in representation between different people. Marr's approach has the interesting quality that different elements of perception are separate processes, but linked by a central system that "constructs" the representation. As a sequential process that is dynamic and incorporates top-down and bottom-up processes, there are elements that are beneficial to conservation assessments. The build-up of visual detail from initial sketches means that the percept increases in depth. Each action involves a different, more detailed level of information from which a percept can be created (table 3).

Criticisms of Marr's (1982) approach are that he has not placed enough emphasis on the variation with perception. This variation would ideally be absent, or at least subdued, in any conservation assessment process, but it is a problem that affects conservation assessments nonetheless. The constructive 


\section{JOEL TAYLOR}

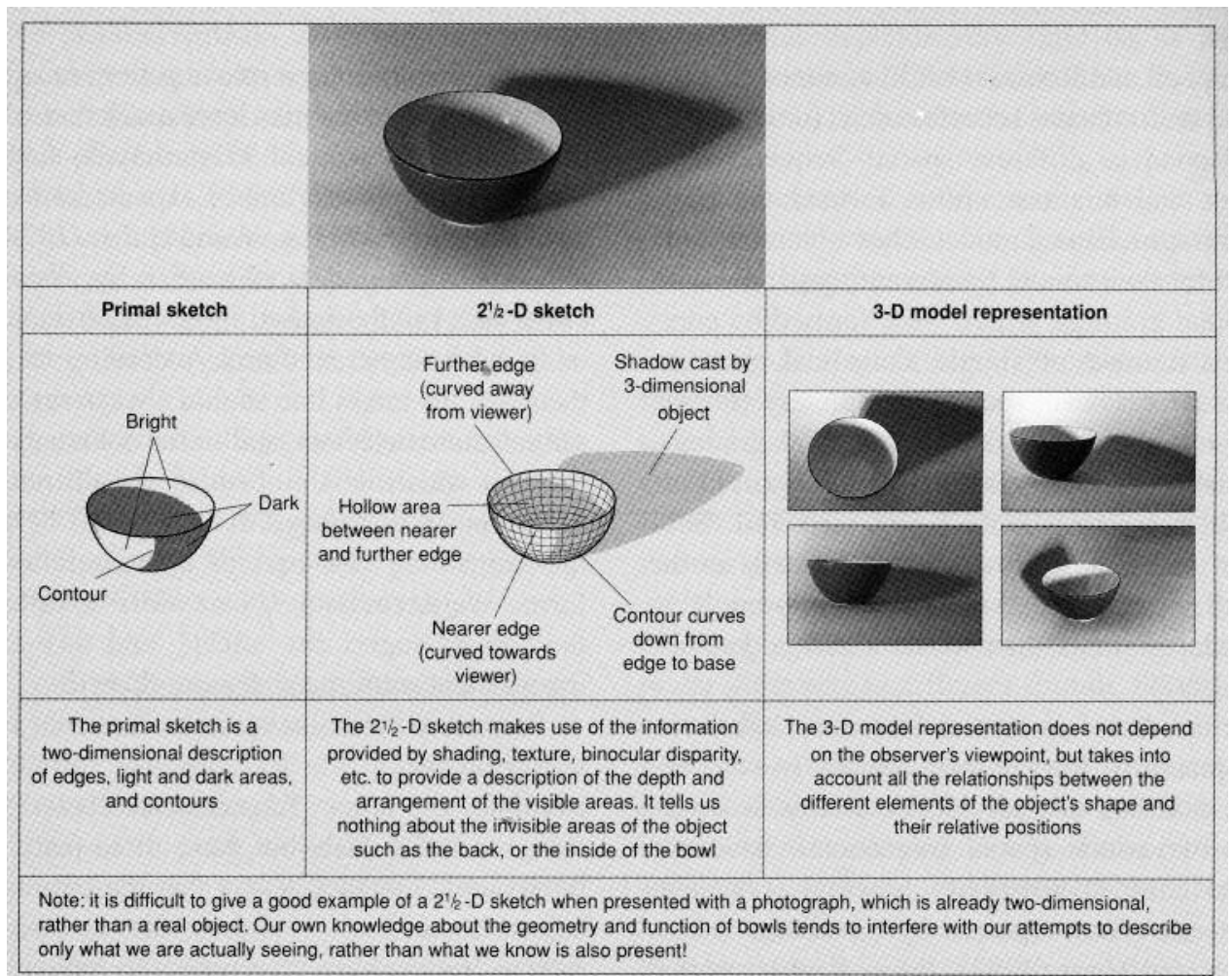

Fig. 5. Marr's (1982) computational approach to perception has three autonomous stages that build to create a detailed, dynamic view of the environment (Eysenck and Keane 2000).

nature of Marr's computational theory is a useful way of understanding how detail and inference can be applied to perception.

While Marr's (1982) process is fundamentally bottom-up (table 3), the knowledge of the perceiver, or conservator, is required to construct the assessment and apply the theoretical framework of object damage that is used to interpret this information. The assessment of risk is based on the knowledge of what to look for, and essentially it is a top-down process. It requires much more interpretation than simply object recognition. Marr's autonomous stages of perception, linked by a central function, illustrate how assessments can be integrated and independent of each other.

If conservation assessment methods are to be complementary, a degree of mutual independence is required. Otherwise, one process can be used to "prove" the efficacy of the other. Basing a condition survey on the results of a risk assessment, or vice versa, may lead to a false confirmation of findings. The possibility of a conservator's pursuing a certain

Table 3. Marr's (1982) Computational Theory of Perception

\begin{tabular}{lll}
\hline Process & Action & Data \\
\hline Primal sketch & $\begin{array}{l}\text { Features of object/light intensity changes are } \\
\text { detected. }\end{array}$ & $\begin{array}{l}\text { Information from the } \\
\text { environment }\end{array}$
\end{tabular}

21/2-D sketch The shape of the object is represented as it appears

Visual system of the perceiver to the perceiver.

3-D model A representation of the object is created, based on Knowledge of the perceiver past experiences of the visual information.

Note: Each process has a different action and collects different kinds of data, which builds up a sophisticated view of the perceiver's environment. 


\section{AN INTEGRATED APPROACH TO RISK ASSESSMENTS AND CONDITION SURVEYS}

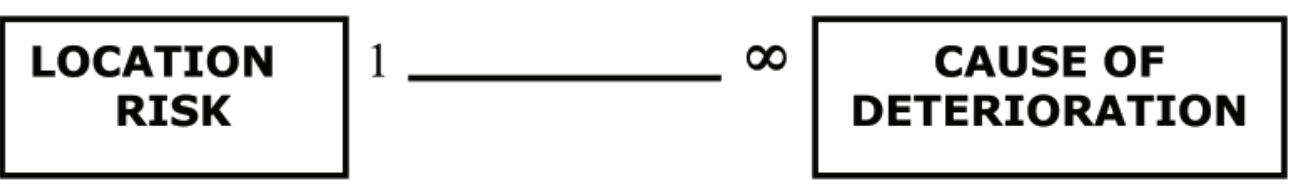

Fig. 6. The one-to-many database relationship that links the independent processes

line can be extended by the reinforcement of a belief through the accumulation of confirmatory evidence. The correlative nature of surveys makes this a real problem because the accumulation of confirmatory evidence will increase this effect (Wason 1960, 1996; Evans 1989).

Risk assessments and condition surveys focus on interpretation in a number of ways, such as the symptoms of damage denoting condition, condition denoting deterioration, or deterioration denoting exposure to hazards. The concepts here are more subtle and ambiguous than object recognition. They require an understanding and interpretation of what the stimuli mean, not just recognition of what they are. This level of understanding requires the addition of knowledge from the perceiver-a top-down process of interpretation. When determining the problems of a collection from conservation assessment records rather than the environment itself, these problems are highlighted. The more information-rich processes are removed, and collected data lose the contextual information.

\section{INTEGRATING RISK ASSESSMENTS AND CONDITION SURVEYS}

The integration of the collection condition survey with the risk assessment can be done by adding a list of probable causes of damage, in addition to damage type, to the condition database. Murray has successfully attributed damage to causes in condition survey design (Edwards and Murray 2002), and the notion is advocated by Ashley-Smith (1997) when practicing conservators are involved. Both the causes and effects of deterioration to an object are based on "risks," and therefore the relationship between hazard and damage can be expressed this way. Establishing a one-to-many database relationship between each hazard and the objects surveyed (fig. 6) means that the list of probable causes is the same list as the risks looked for in the risk assessment. As a result, the visible impact of each risk can be viewed in terms of collection condition.

This link acts as the connecting pathway between separate assessments, similar to Marr's (1982) theory of perception. The format of risk assessment can be based on Waller's (1999) equation of risk-P $\times$ FS $\times$ E x LV-in which scores allow locations, collections, and risks to be compared and given priorities, where $\mathrm{P}$ is probability of damage, FS is the fraction of the collection susceptible to damage, $\mathrm{E}$ is the extent of damage, and LV the expected loss of value. Waller's "Loss of Value" (Waller 1999) is, of course, expected loss from which the condition is the result.

This simple method allows probable causes of damage to be related to actual risks, so an immediate idea of which deterministic risks are having an impact on the collection can be established. It is not always possible to precisely determine causes of deterioration, and there may well be more than one (Koestler et al. 1994; Ashley-Smith 1999, 2000), so several causes can be added to the object section. The method consequently addresses the problem associated with cause-effect relationships mentioned in table 1. Risks need to be designated one category in assessment to reduce potential for the same risk to be recorded twice (Waller 2003). This connection to various possible causes of deterioration offers an insight into synergistic effects of risks to collections.

Using a one-to-many relationship, the connection is logically valid. The fact that different causes may be attributable to a given effect is acknowledged in this relationship. The problems associated with inference of cause from effect, mentioned in table 1 , are reduced.

Taylor and Watkinson (2003) point out that the difference in deterioration mechanisms for different materials can be helpful. Causes attributed erroneously for one material would not be recorded for other materials. For example, possible causes of discolored paper may be high temperature, high RH, external pollutants, inherent instability, or a combination of these. Metalwork may indicate that corrosion is present, and high $\mathrm{RH}$ the cause, stone may show 


\section{JOEL TAYLOR}

salt efflorescence, and wood may show dimensional change or mold. The real causes are drawn out because of these differences in effect. Therefore, the impact of recording any erroneous causes will be limited to particular types of material, where real causes would be consistent among different materials. The attribution of these causes is something that would be consistent in a risk assessment but not in a condition survey.

For preventive conservation, however, not all damage provides useful information. As mentioned earlier, damage that took place before an object entered a museum does little to indicate the effect of its present environment. Damage that clearly relates to past environments, such as broken archaeological ceramics, should be omitted, as it does not determine if an institution is "succeeding in its basic duty to preserve collections" (Keene 2002, 139). Condition scoring is similar to that of Keene's "stability," although it is not "predicting the rate at which an object is likely to deteriorate" (Keene 2002, 147). "Stability" is the forecast of risk to single objects rather than to the whole collection from risk exposure, and it overlaps with the risk assessment. Waller (2003) points out problems with this approach, using an example of contamination from old treatment methods not indicating contamination from future treatment methods. Such damage may indicate a greater instability of treated objects to environmental risks but cannot help forecast future treatments. It is intended that only risk assessments look at forecast damage, and condition surveys look at existing effects. Only damage that can be observed, rather than used for forecasting, should be recorded. "Present" condition is suitable for many type 3 risks, and "recent" damage is suitable for risks such as handling and pests. Evidence of damage from known hazards is important for the overall assessment. Inherent object instability, such as salt efflorescence from buried ceramics or yellowing from poorly processed cellulose nitrate negatives, should be identified because it has implications for preventive conservation decisions. The worse the kind of damage identified, the more indicative of a threat to the collection. For example, high $\mathrm{RH}$ might facilitate corrosion that could be a threat, in the case of hematite, or comparatively benign, in the case of patina.

Surveying condition must take into account recent movements of objects and factors that might create discrepancies between assessments of risk and condition. Existing damage is sometimes hard to attribute to particular risks. An example is UV and visible radiation, where fading could have taken place at any time. However, the circumstances around an object, such as being in a box or on open display and faded only in parts where the object is exposed to display lighting, will allow one to make a judgment. There may be occasions when a risk is not present at all (Waller 2003), which will inform the condition survey in terms of identifying past damage. As mentioned earlier, some damage types are easy to omit, and odd occurrences are reduced by using a large sample of objects. Having to consider several possible causes of deterioration means that any correlation of risk and condition is not direct, but this correlation is not always the case in reality either (Ashley-Smith 2000), and the consideration of several possible causes makes the determination of synergistic effects easier.

Discrepancy between risk and condition does not necessarily mean that one or the other is correct, but it allows expectation and observation to be integrated to focus on any uncertainty, whether that is due to assessment or object behavior. Cognitively, addressing such discrepancies increases performance in real-life reasoning situations (Dunbar 1993).

The relationship between risk and condition does change with the type of risk, but all risks have a connection to condition at some level. All interpretation is clearly based on the relationship between hazard and damage. The strongest relationship is, of course, with deterministic risks, but all kinds of recent damage can help refine present or future assessments. Table 4 illustrates the different relationships that different types of risk have with condition. The relationship is stronger between type 3 risks and condition surveys, but risk assessments are well suited to type 1 risks. Corroboration between a risk assessment and condition survey indicates both "exposure" and "consequence" of risk. Lack of corroboration may be due to a number of reasons, such as damage that has been over- or underestimated, risk that has been over- or underestimated, a lack of visible effects, or damage occurring outside expected bands of preservation or not occurring in conditions expected to promote deterioration.

\section{ENGLISH HERITAGE APPROACH}

This concept has since provided the theoretical underpinning for a conservation assessment 


\section{AN INTEGRATED APPROACH TO RISK ASSESSMENTS AND CONDITION SURVEYS}

currently being carried out by English Heritage for its 134 properties containing collections. The conservation assessment is an application of the risk assessment-condition survey concept described, and carried out by the Collections Conservation Team.

This process started in May 2003 and is ongoing. A desire to consistently prioritize the different preventive actions over a broad range of properties, as well as evidence that the collections needed preservation, was required. These assessments are often the only time that conservators can systematically examine sites and collections spread across the country.

The Collections Conservation Team is small, with a large number of collections, and is mostly concerned with preventive conservation. The conservation assessment is intended to provide a solutions-based approach to collections management. Given the number of locations, the Collections Conservation Team had already built up a range of activities such as training and collections care systems for site staff to use. The direction of these programs and other preventive conservation activities were to be established by risk management.

The possibility of mitigating risks that are not a threat to the collection, when those resources can be spent elsewhere, was considered, as well as the possibility that collections are vulnerable to environments that appear to be suitable.

Because similar information was required for the two processes, such as the kind of collection, details of the location, and the value of the collection, the integration of the assessments had the benefit of the same information being useful to both processes and collected only once. The process carried out the collection condition survey first. Surveying collection condition also helped to refine estimations of the kinds and quantities of materials present in certain locations. ${ }^{1}$ Location notes were written as well, to provide more detail and help with the mitigation of identified risks. Environmental information was not readily available in all of the 134 sites, so the risk assessment was sometimes difficult, but it could be refined because of the collection condition survey system.

There was often evidence of hazards that did not significantly contribute to an object's deterioration. In practice, it was determined that causes of deterioration should be regarded as major or minor and treated separately. The condition grade was attributed to the major causes of deterioration, if any, and minor causes were not included when more significant damage was present.

The risks chosen were tailored to the solutionsbased approach of the team. As a result, display and storage materials were looked at as a risk, and disasters were categorized as one overall risk, since disaster prevention and training are carried out at the same time. Inherent deterioration of objects was an added risk, since object deterioration and lack of exposure may indicate that the objects themselves are unstable, and this factor would affect the selection of options for mitigation and explain the possibility of deterioration in benign environments.

The assessment of risk involves two scores-one that assesses probability, the fraction susceptible and loss, based on Waller's (1999) magnitude of risk, and a second that includes curatorial value. ${ }^{2}$ The risk to the collections can be related to condition without the value of the collections influencing this comparison. The overall risk score could be used to make deci-

Table 4. The Relationship Between Condition Data and Risk

\begin{tabular}{ll}
\hline Risk Type & Relationship to Condition Data \\
\hline Type 3 risks & $\begin{array}{l}\text { Condition data can falsify and corroborate forecasted risk of deterministic, type } 3 \\
\text { risks. }\end{array}$ \\
Type 2 risks & $\begin{array}{l}\text { Condition data can verify the existence of certain type } 2 \text { risks, such as pest } \\
\text { infestations and poor handling, but cannot discount the possibility of future } \\
\text { occurrences. }\end{array}$ \\
Type 1 risks & $\begin{array}{l}\text { There is little relationship between type } 1 \text { risks and condition assessment at an } \\
\text { early stage, but as Ashley-Smith (1999) and Waller (2002) point out, continued } \\
\text { assessment of object damage can lead to refined judgements of risk in the future } \\
\text { (and assess the predictive validity of the forecasted risk). }\end{array}$
\end{tabular}

Note: The relationship changes with the type of risk, the clearest association being with deterministic, type 3 risks, based on Waller's (1994) risk typology from figure 1. 


\section{JOEL TAYLOR}

sions based on the value of the collections. The scoring can be done using Waller's (2003) system but it was altered for the team's purposes.

Current results indicate that there is a difference between risk scores and condition scores for all types of risk, as well as correlation of risk scores and existing damage.

\section{CONCLUSION}

Risk assessments and condition surveys are both valuable tools for the conservator, which aid planning and direction of resources. These complementary techniques have something to offer each other in terms of interpreting and planning for preventive conservation issues, as well as understanding collection deterioration in terms of synergistic factors. The problems of inferring a relationship between risks and collection condition are manifold, but the integration of risk assessments and condition data can help reduce some of these problems by the creation of a relationship between these assessments. The field of visual perception illustrates the similarities and differences between expected and observable deterioration and how seemingly conflicting approaches have been integrated. By doing this, potential problems of both can be reduced, and the data of each given greater context and meaning.

Basing judgments about mitigation on empirical evidence, where it exists, allows the conservator to allocate resources effectively and avoid over- and underestimation of risks, discussed by Waller (2003). Also, the synergistic effects of various hazards may also be recognized, since there will be a connection between the kinds of risk and the kinds of damage. This connection does not exist in either of the individual methods.

Risk assessment gives condition data a framework for interpretation that provides meaning and context to observation. Condition surveys alone have a very limited predictive value (Waller 2002, 2003), and risk assessment provides that-independent of past damage that may affect the survey.

Decisions based on risk assessment have the benefit of projection that Waller (2002) advocates, and many potential difficulties of projecting deterioration from past damage alone are avoided. Judgments cannot be evaluated entirely by outcomes, as Waller (2002) points out, but collection condition does have a role to play in assessing all types of risk.

\section{ACKNOWLEDGMENTS}

Gratitude goes to Amber Xavier-Rowe and Claire Smith (English Heritage) for their application of these ideas, discussions, and development of the database; Frances Halahan, Jennifer Dinsmore, and Sophie Budden (Halahan Associates) for carrying out the assessments and discussions; David Watkinson (Cardiff University) and Jonathan Ashley-Smith for discussions and comments on drafts; May Cassar (UCL, Centre for Sustainable Heritage) and Dermot Taylor and Geraldine Taylor for comments on drafts; and the editorial team for their comments.

\section{NOTES}

1.The process of using the condition survey to refine estimates of material types was devised by Halahan Associates while carrying out the English Heritage audit.

2. Discussion with Claire Smith, senior collections conservator, was the basis for demarcating between risk scores with and without value. Risk scores with value determine the overall priority for the Collections Conservation Team; risk scores without value determine the projected deterioration of a collection from a given risk.

\section{REFERENCES}

Ashley-Smith, J. 1997. Risk analysis. In The interface between science and conservation, ed. S. Bradley. British Museum occasional paper 116. London: British Museum Press. 123-32.

Ashley-Smith, J. 1999. Risk assessment for object conservation. Oxford: Butterworth-Heinemann.

Ashley-Smith, J. 2000. Developing professional uncertainty. In Tradition and innovation: Advances in conservation, ed. A. Roy and P. Smith. London: International Institute for the Conservation of Historic and Artistic Works. 14-17.

Best, J. B. 1995. Cognitive psychology. 4th ed. Minneapolis: West.

Bradley, S., and D. Thickett. 1999. The pollution problem in perspective. ICOM Committee for Conservation preprints. 12th Triennial Meeting, Lyons. London: ICOM. 1:8-13. 


\section{AN INTEGRATED APPROACH TO RISK ASSESSMENTS AND CONDITION SURVEYS}

Chalmers, A. F. 1999. What is this thing called science? 3rd ed. Milton Keynes, U.K.: Open University Press.

Crumly, C. R. 1984. Saving a legacy: Natural history collections in Germany before and after World War II. Curator 27(3):205-19.

Dunbar, K. 1993. Concept discovery in a scientific domain. Cognitive Science 17(3):397-434.

Eden, P., N. Dungworth, N. Bell, and G. Matthews. 1998. A model for assessing preservation needs in libraries. British Library Research and Innovation Report 125. London: British Library.

Edwards, D., and W. Murray. 2002. Condition assessment tool manual: A manual for using the condition assessment tool (CAT) database. Scottish Museums Council, Edinburgh, U.K.

Erhardt, D., and M. Mecklenburg. 1994. Relative humidity re-examined. In Preventive conservation: Practice, theory and research. Preprints of the Congress on Preventive Conservation: Practice, Theory and Research, Ottawa. London: International Institute for the Conservation of Historic and Artistic Works. 31-38.

Evans, J. St. B. T. 1989. Bias in human reasoning: Causes and consequences. Hove, Sussex, U.K.: Lawrence Erlbaum Associates.

Eysenck, M. W., and M. T. Keane. 2000. Cognitive psychology: A student's handbook. 4th ed. Hove, Sussex, U.K.: Lawrence Erlbaum Associates.

Fenn, J. 1995. The cellulose nitrate time bomb: Using sulphonephthalein indicators to evaluate storage strategies. In From marble to chocolate: The conservation of modern sculpture. London: Archetype. 87-92.

Gibson, J. J. 1974. Perception of the visual world. Westport, Conn.: Greenwood Press.

Gibson, J. J. 1979. The ecological approach to visual perception. Boston: Houghton Mifflin.

Gordon, I. E. 1989. Theories of visual perception. Chichester, West Sussex, U.K.: John Wiley and Sons.
Gregory, R. L. 1972. Visual illusions. In New horizons in psychology, vol. 1, ed. B. M. Foss. Harmondsworth, Middlesex, U.K.: Penguin.

Gregory, R. L. 1974. Concepts and mechanisms of perception. London: Duckworth.

Gregory, R. L. 1998. Eye and brain: The psychology of seeing. 5th ed. Oxford: Oxford University Press.

Gross, R. D. 2001. Psychology: The science of mind and behaviour. 5th ed. London: Hodder and Stoughton.

Grzywacz, C.M., and N. Tennent. 1994. Pollution monitoring in storage and display cabinets: Carbonyl pollutant levels in relation to artefact deterioration. Preprints of the Congress on Preventive Conservation: Practice, Theory and Research, Ottawa. London: International Institute for the Conservation of Historic and Artistic Works. 165-70.

Johnsen, J. S. 1994. Surveying large collections of photographs for archival survival. Preprints of the Congress on Preventive Conservation: Practice, Theory and Research, Ottawa. London: International Institute for the Conservation of Historic and Artistic Works. 202-6.

Johnsen, J. S. 1999. Introduction to the surveyor's guide to condition assessment of photographic collections. ICOM Committee for Conservation preprints. 12th Triennial Meeting, Lyons. London: ICOM. 2:555-60.

Johnsen, J. S., and K. Bonde-Johansen. 2002. Condition survey and preservation strategies at the Danish Film Archive. ICOM Committee for Conservation preprints. 13th Triennial Meeting, Rio de Janeiro. London: ICOM. 2:644-50.

Julien, S. 2001. Challenging mould problems: Case studies in historic houses. Poster presented at the FUNGI: A Threat for People and Cultural Heritage Through Micro-organisms conference, Munich, Germany.

Keene, S. 1991. Audits of care: A framework for collections condition surveys. In Storage. ed. M. Norman and V. Todd. London: United Kingdom Institute for Conservation. 6-16. 


\section{JOEL TAYLOR}

Keene, S. 1994. Real-time survival rates for treatments of archaeological iron. Ancient and historic metals: Conservation and scientific research, ed. D. A. Scott et al. Santa Monica: GCI. 249-64.

Keene, S. 2002. Managing conservation in museums. 2nd ed. London: Butterworths Heinmann.

Koestler, R. J., P. Brimblecombe, D. Camuffo, T. E. Ginell, P. Leavengood, J. Petushkova, M. Steiger, C. Urzi, V. Verges-Belmin, and T. Warscheid. 1994. How do external environmental factors accelerate change? In Durability and change: The science, responsibility and cost of sustaining cultural heritage, ed. W. E. Krumbein et al. Chichester, West Sussex, U.K.: John Wiley and Sons. 149-63.

Marcon, P. 1997. Decision support models for preventive conservation. In The interface between science and conservation, ed. S. Bradley. British Museum occasional paper 116. London: British Museum Press. 143-51.

Marr, D. 1982. Vision: A computational investigation into the human representation and processing of visual information. New York: Freeman.

Michalski, S. 1990. An overall framework for preventive conservation and remedial conservation. ICOM Committee for Conservation preprints. 9th Triennial Meeting, Dresden. London: ICOM. 2:589-91.

Michalski, S. 1994. A systematic approach to preservation: Description and integration with other museum activities. Preprints of the Congress on Preventive Conservation: Practice, Theory and Research, Ottawa. London: International Institute for Conservation of Historic and Artistic Works. 8-11.

Neisser, U. 1968. The processes of vision. Scientific American 219(3):204-14.

Neisser, U. 1976. Cognition and reality: Principles and implications of cognitive psychology. San Francisco: Freeman.

Newey, H. M., S. M. Bradley, and M. N. Leese. 1993. Assessing the condition of archaeological iron: An intercomparison. ICOM Committee for Conservation preprints. 10th Triennial Meeting, Washington. London: ICOM. 2:786-91.
Oaksford, M., and N. Chater. 1998. Rationality in an uncertain world: Essays on the cognitive science of human reasoning. Hove, Sussex, U.K.: Psychology Press.

Padfield, T. 1994. The role of standards and guidelines: Are they a substitute for understanding the problem or a protection against the consequences of ignorance? In Durability and change: The science, responsibility and cost of sustaining cultural heritage, ed. W. E. Krumbein et al. Chichester, West Sussex, U.K.: John Wiley and Sons. 191-99.

Purewal, V. J. 1997. An investigation into the composition of botanical wax models with a view to their conservation. Collection Forum 13:11-19.

Resnick, M. 1994. Termites, turtles and traffic jams: Explorations in massively parallel microworlds. Cambridge, Mass.: MIT Press.

Taylor, J., and S. Stevenson. 1999. Investigating subjectivity within collection condition surveys. Journal for Museums Management and Curatorship 18(1):19-42.

Taylor, J., and D. Watkinson. 2003. Using multiple hypotheses in collection condition surveys. Conservator 27:13-22.

Thomson, G. 1986. The museum environment. 2nd ed. London: Butterworths.

Tversky, A., and D. Kahneman. 1974. Judgment under uncertainty: Heuristics and biases. Science 185:1124-31.

Van der Reyden, D., H. Tennison, and F.W.Tsai. 1996. Publish then perish: The reclamation of a collection of scientific illustrations. Restaurator 17(2):104-15.

Van Oosten, T. B. 2002. A survey of problems with "early" plastics. In Contributions to conservation, ed. J. A. Mosk and N. Tennent. London: James and James. 87-96.

Waller, R. 1994. Conservation risk assessment: A strategy for managing resources for preventive conservation. Preprints of the Congress on Preventive Conservation: Practice, Theory and Research, Ottawa. London: International Institute for the Conservation of Historic and Artistic Works. 12-16. 


\section{AN INTEGRATED APPROACH TO RISK ASSESSMENTS AND CONDITION SURVEYS}

Waller, R. 1999. Internal pollutants, risk assessment and conservation priorities. ICOM Committee for Conservation preprints. 12th Triennial Meeting, Lyons. London: ICOM. 1:113-18.

Waller, R. 2002. A risk model for collection preservation. ICOM Committee for Conservation preprints. 13th Triennial Meeting, Rio de Janeiro. London: ICOM. $1: 102-7$.

Waller, R. 2003. Cultural property risk analysis model: Development and application to preventive conservation at the Canadian Museum of Nature. PhD diss., University of Göteborg, Sweden.

Wason, P. C. 1960. On the failure to eliminate hypotheses in a conceptual task. Quarterly Journal of Experimental Psychology 12(3):129-40.

Wason, P. C. 1996. Foreword. In Rationality and reasoning, J. St. B. T. Evans and D. Over. Hove, Sussex, U.K.: Psychology Press.
JOEL TAYLOR graduated from Cardiff University with a BS in archaeological conservation in 1996. He has had an interest in collection surveys since then, conducting research in this field as an undergraduate, for which he won the Jerwood Foundation "Student Conservator of the Year" award in the United Kingdom. He has continued this interest, now reading part-time for a $\mathrm{PhD}$. He worked as a housekeeper and objects conservator in the Museum of Welsh Life (National Museums and Galleries of Wales) before joining English Heritage in 1999 as its first environmental management intern, then collections conservator and senior collections conservator. He now works as a research fellow at the University College London (UCL) Centre for Sustainable Heritage. Address: Centre for Sustainable Heritage, Bartlett School of Graduate Studies, University College London, Gower Street, London, WC1E 6BT, UK. email: joel.taylor@ucl.ac.uk

Received for review on January 30, 2004. Accepted for publication on May 4, 2005. 